\title{
Adolescent Mother and Child Abuse
}

Miguel Oliveros Donohue M.D.

Principal Professor of the Department of Pediatrics and Member of the Ethics Institute of the San Fernando Medical School, Universidad Nacional Mayor de San Marcxs.

* Corresponding Author: Miguel Oliveros Donohue M.D., Principal Professor of the Department of Pediatrics and Member of the Ethics Institute of the San Fernando Medical School, Universidad Nacional Mayor de San Marcxs..

Received date: September 06, 2020; Accepted date: October 23, 2020; Published date: November 02, 2020

Citation: Miguel Oliveros Donohue (2020) Adolescent Mother and Child Abuse. J Obstetrics Gynecology and Reproductive Sciences. 4(3); DOI: $10.31579 / 2578-8965 / 051$

Copyright: (C) 2020 Miguel Oliveros Donohue, This is an open-access article distributed under the terms of the Creative Commons Attribution License, which permits unrestricted use, distribution, and reproduction in any medium, provided the original author and source are credited.

\section{Introduction}

Adolescence is the process that occurs after childhood and before adulthood (15-19) years. Teenage pregnancy is adverse for the mother and her child including low birth weight and high perinatal mortality. Complications between pregnancy and childbirth are the second leading cause of death among girls between the ages of 15 and 19 in the world. Violence against a pregnant woman by her partner is frequent. Adolescent mothers are among the greatest abusers of their children, and abuse can start from fetal life. They are also involved in the death of their newborns. Educational and community empowerment with a family response to educational proposals includes the issue of masculinity and the role of adolescents caring for their children, as well as examining the families' pleasure in the prevention and response to pregnancy.

\section{What are teenage mothers?}

The WHO defines adolescence as the process of human growth and development that occurs after childhood and before adulthood, between 10 and 19 years of age. Some 16 million girls between the ages of 15 and 19 and approximately one million girls under the age of 15 give birth each year, the majority in low- and middle-income countries. Complications between pregnancy and childbirth are the second leading cause of death among 15-19 year-old girls worldwide (1).

\section{Why do they get pregnant at such a young age?}

Teen pregnancy is an issue that requires more education and support to encourage girls to delay motherhood until they are ready. It is a culturally complex problem because cultural issues influence sexual behavior (2). Adolescent births range from 2\% in China to 18\% in Latin America and the Caribbean (3). In the US in 2017, 194,377 newborns were born to women between 15-19 years old, with an incidence of 18.8 x 1000 pregnancies in this age group (4).

\section{How are you doing during your pregnancy?}

Pregnancy during adolescence is adverse for the mother and her child, including low birth weight (5). Many of them have a history of abuse at home and are vulnerable to poor delivery outcomes. Lack of prenatal or late care, stress, and adverse school, parental, and social conditions affect fetal life. The adverse conditions mentioned can induce them to use drugs or engage in high-risk behaviors (6).
There are studies that show reduction and isolation of social life, presence of stigma, school dropout, lack of opportunities for personal development and perception of goals, economic problems and parental disapproval (7).

\section{How does the couple behave?}

Violence against the pregnant partner is frequent, it is associated with damage to the health of the mother and fetus, and poor social outcomes (8).

Daoud, in a Canadian study indicates a prevalence of violence of $10.6 \%$ : before pregnancy $6 \%$, during pregnancy $1.4 \%$, and postpartum $1 \%$ (9). The pregnant adolescent is very vulnerable socially (risk of dropping out of school, fewer educational opportunities and lack of support from family or social networks). The frequent consumption of alcohol by men is added (10). Verbal violence consists of: name calling, ridicule and humiliation. Physical violence by pulling the arm or the hair and pushing. Direct assault by punching, slapping, kicking, and burning. Sexual violence for sexual relations without consent $(10,11)$.

\section{How is child abuse defined?}

Any intentional aggression or omission, inside or outside the home that occurs before or after birth, affecting the bio-psychosocial integrity of the child, carried out habitually or occasionally by a person, institution or society, child based on their physical superiority or intellectual (12). If the newborn lacks care and affection, he could develop an attachment disorder with a high risk of the relationship he will have with his mother, a primary affective bond that guarantees survival. The purpose of the link is to search for proximity. Negative attachment experiences create mistrust in the mother-child relationship and future pessimistic expectations of emotional neglect (13). The high relational risk manifested by lack of attachment may be related to child abuse (14). The attachment is strengthened with exclusive breastfeeding and joint accommodation.

\section{What type of child abuse is most common?}

Teen mothers are among the biggest abusers of their children. The perinatal mortality of adolescent mothers is 2.4 times higher than mothers aged 20 to 24 years. Maternal aggression has been the most varied: ignoring them, patting them, forbidding something they like, restricting feeding, hitting, locking them up, with more work, leaving them outside 
the house, pouring water on them, taking away their clothes or belongings, and removing their support (15-19).

The social development of women through education and human solidarity are more important determinants than the simple age of the mother. The social and emotional support of the family can reverse this situation.

\section{What is perinatal abuse?}

Fetal abuse is any act that intentionally or negligently can injure the fetus, one of these conditions is the maternal use of drugs during pregnancy (twenty). Neonatal abuse includes deliberate aggressive actions with the baby such as: not looking at him, being rough when changing or grooming him, yelling or shaking him when he cries, leaving him alone in the room, not taking him to the doctor's office or ignoring instructions, do not breastfeed, skip feeding or change schedules, do not vaccinate or facilitate attachment (21)

\section{Why do teenage mothers cause the death of their newborns?}

The profile of the woman who commits the neonaticide (death in the neonatal period) is a young, single, primiparous woman, lives with her parents, with no previous psychiatric history, a low degree of psychopathology, carries the pregnancy clandestinely and ends up with the child within minutes of being born. Resnick, studied 34 mothers who killed their newborns and $81 \%$ of them fit the indicated profile (22). Stock, in a systematic review of 126 publications, found that $36.9 \%$ of adolescents were the ones who committed the most homicides (23). Gidden, of 34 NBs who died in 24 cases, the perpetrator was the mother, $50 \%$ single, aged 18 years or more (24). They are generally unwanted, illegitimate children, an obstacle to personal aspirations with financial problems and sometimes sexual assault. Paternal neonaticide is rare.

\section{How to reduce pregnancy in adolescence?}

The educational and community empowerment of adolescents allows the development of interaction with parents and cultural practices. The success in reducing teenage pregnancy has been the policy of social empowerment working with young people, making them aware of the rights and risks of early sexual relationships. The family's response to educational policies has largely reduced the potential negative impact of adolescent girls' lives. Much attention has been paid to the issue of gender and sexuality including the terms and conditions under which teens have sex. A critical reflection and commitment with men and boys on the issue of masculinity is necessary, including their role in raising children, as well as examining their liking among families, accepting prevention and response to pregnancy $(25,26)$.

WHO mentions as strategies: Limit marriage before age 18, Create understanding and support to reduce pregnancies before age 20, Increase use of contraceptives by adolescents, and Reduce coerced sex in adolescents ( 27).

\section{Conclusions}

Adolescent mothers (15-19 years old) are among the greatest abusers of their children, and the aggression is varied: verbal, physical, psychological and sexual. They cause the death of their children in the neonatal stage, and have a profile that characterizes them: single, primiparous, lack a psychiatric history, live with their parents, carry a clandestine pregnancy and end their children's lives within a few minutes of birth. Educational and community empowerment allows them interaction with parents and cultural practices. The WHO mentions as strategies: reducing pregnancy before age 20, reducing forced sexual intercourse, increasing the use of contraceptives and limiting marriage before age 18 .

\section{References}

1. OMS. Embarazo en la adolescencia. www.who.int/topics/maternal/adolescent_pregnancy

2. Boletín Organización Mundial de la Salud. Embarazo en la adolescencia un problema cultural complejo. Volumen 87, Junio 2009:405-484

3. Monteiro Maia D.L, Ferraz dos Santos J.A, Pinheiro Rodríguez N.C y col. Adolescent pregnancy trends in the last decade. Rev Assoc Med Bras 2019;65(9): Oct

4. Martin JA, Hamilton BE, Osterman MJK. Births in the United States, 2017. NCHS data brief. 2018 (318):1-8.

5. Roth J, Hendrickson J, Schilling M, Stowell D.W. The risk of teen mothers having low birth weight babies. Implications of recent medical research for school Health Personnel. Journal of School Health 1998;68(7):271-5

6. Fajardo Ochoa F, Olivas Pununuri M.R. Abuso fetal por consumo materno de drogas durante el embarazo. Bol Clin Hosp Infant Edo Son 2010;27(1):9-15

7. Jewell D, Tacchi J, \& Donovan J. Adolescents from different socioeconomic backgrounds had different attitudes about teen pregnancy. Evidence based Nursing 2001; 4:125

8. Rome E.S, Miller E. Intimate partner violence in the adolescent. Pediatric in Review 2020;41(2):73-80

9. Daoud N, Urquia M.L, O’Campo P, Heaman M, Janssen P.A, Smylie J, et al. Prevalence of abuse and violence before, during and after pregnancy in a national sample of Canadian women. Am J Public Health 2012;102(10):1893-901

10. Monterrosa Castro A, Arteta Acosta C, Ulloque Caamaño L. Violencia domestica en adolescentes grávidas: caracterización de la pareja y prevalencia de las formas de expresión. Iatreia 2017;30(1):Jan/Mar Medellín

11. Contreras Pulache H, Mori Quispe E, Hinostroza Camposano W.D, Yanca Chajilla Apaza M, Lam Figueroa N, Chacón Torrijo H. Características de la violencia durante el embarazo en adolescentes de Lima, Perú. REV PERU MED EXP SALUD PUBLICA 2013; 30(3:379-85

12. ONU. Derechos del niño. Informe del experto independiente de las naciones unidas para el estudio de la violencia contra los niños www.violencestudy.org/IMG/Spanish

13. Muñoz M, Poo A.M, Baeza B, Bustos L. Riesgo relacional Madre- recién nacido. Estudio de prevalencia y variables asociadas. Rev Chil Pediatr 2015;86(1):25-31

14. Lecannelier, F.; Kimelman, M.; González, L.; Nuñez, C.; Hoffmann, M. Evaluación de Patrones de Apego en Infantes Durante su Segundo Año en Dos Centros de Atención de Santiago de Chile Revista Argentina de Clínica Psicológica, vol. XVII, núm. 3, noviembre, 2008, pp. 197-207 Fundación Aiglé Buenos Aires, Argentina

15. McCullough M, Sherman A. Family of origin interaction and adolescent mother's potential for child abuse. Adolescence 1998;33(130):375-84.

16. Buchholz ES, Korn-Bursztyn C. Children of adolescent mothers: are they at risk for abuse? Adolescence 1993:28(110):361-82.

17. Zelenko MA, Huffman L, Kennedy Q, Steiner H. Poor adolescent expectant mothers: can we assess their potential for child abuse? J. Adolesc Health 2001(4):271-8. 
18. Cederbaum J.A, Putnam Hornstein E, King Bryn, Kaycee Gilbert B.A, Needell B. Infant birth weight and maltreatment of adolescent's mothers. A J Prev Med 2013;45(2):197-201

19. Oliveros M, Pacora P. Maltrato infantil ocasionado por la madre adolescente. Diagnostico 2007;46(3):138-141

20. Fajardo Ochoa F, Oliva Pununuri M.R. Abuso fetal por consumo materno de drogas durante el embarazo. Bol Clin Hosp Inf Edo Son 2010;27(1):9-15

21. Paolini C.I. Violencia perinatal. Una nueva conceptualización. III Congreso Internacional de Invstigación y Práctica Profesional en Psicología. Sétimo encuentro de investigadores en Psicología del MERCOSUR. Facultad de Psicología. Universidad de Buenos Aires, 2011

22. Resnick P.J. Murder of a newborn: a psychiatric review of neonaticide. Am J of Psychiatry 1970; 126:1414-20

23. Stockl H, Dekel B, Morris Gehring A, Watts Ch, Abrahams N. Child homicide perpetrators worldwide. A systematic review. BMJ Paediatrics Open 2017;00012

24. Herman Giddens M.E, Smith J.B, Mittal M, Carlson M, Budds J.D. Newborn killed or left to die by a parent: a populationbased study. JAMA 2003; 289:1425

25. Christofides N. Empowering teenagers to Prevent Pregnancy. Lessons: from South Africa. Culture Health and Sexuality 2009;11(7):675-88

26. Dumisani Enricho Nkhoma, Chia-Ping Lin, Hexin Latumer Katengeza, Charles Jenya Soko, Wanda Estinfort, Yao-Chin Wang, Shing-Hwa Juan, Wen-Shan Jian and Usman Iqbal. Girl's empowerment and adolescent pregnancy: A systematic review. International Journal of Environmental Research and Public Health. 2020; 17:1664

27. WHO. Prevenir el embarazo precoz. www.intqlibdoc.who.intWHO 